\title{
Fossichnus solus and Oichnus simplex, two peculiar ichnospecies in modern benthic foraminifera from a polluted area in SW coast of Sardinia, Italy
}

\author{
Carla BUOSI ${ }^{*}$, Antonietta CHERCHI ${ }^{1}$, Pierpaolo ZUDDAS ${ }^{2}$ \& Giovanni DE GIUDICI ${ }^{1}$
}

${ }^{1}$ Dipartimento di Scienze Chimiche e Geologiche, Università degli Studi di Cagliari, Via Trentino 51, 09127 Cagliari, Italy;
cbuosi@unica.it; acherchi@unica.it; gbgiudic@unica.it
² Institut des Sciences de la Terre de Paris, Université Pierre et Marie Curie, Paris-Sorbonne, place Jussieu 4, 75252 Paris
Cédex05, France; pierpaolo.zuddas@upmc.fr

* Corresponding author

Buosi, C., Cherchi, A., Zuddas, P. \& De Giudici, G. 2014. Fossichnus solus and Oichnus simplex, two peculiar ichnospecies in modern benthic foraminifera from a polluted area in SW coast of Sardinia, Italy. [Fossichnu solus y Oichnus simplex, dos peculiares icnoespecies en foraminíferos bentónicos actuales de un área contaminada en la costa SO de Cerdeña, Italia]. Spanish Journal of Palaeontology, 29 (1), 71-82.

\begin{abstract}
The modern benthic foraminiferal tests collected from a coastal area of south-western Sardinia (PortoscusoPortovesme) that is heavily polluted by industrial activity reveal intense and widespread bioerosional structures induced by diversified microborers. A large number of the foraminifera reveals microscopic round holes (1-60 $\mu \mathrm{m}$ in diameter) and roundish concavities $(25 \times 40 \mu \mathrm{m}$ in external diameter) on their surface that belong, respectively, to the ichnospecies Oichnus simplex Bromley, 1981, and Fossichnus solus Nielsen et al., 2003. These traces just occur in the tests of the foraminifera which are heavily infested by microendolithic cyanobacteria, algae and fungi suggests comparable ethological behaviour between the ichnospecies Fossichnus and Oichnus and the microbial euendoliths that are ascribed to individual biological taxa. The greater occurrence of $F$. solus and $O$. simplex in the high-Mg foraminiferal porcelanaceous tests than in the low$\mathrm{Mg}$ foraminiferal hyaline tests reveals that the bioerosional
\end{abstract}

\section{RESUMEN}

Los caparazones de foraminíferos bentónicos actuales recolectados en un área costera al sudoeste de Cerdeña (Portoscuso-Portovesme) que está altamente contaminada por la actividad industrial presentan intensas y extensas estructuras de bioerosión inducidas por diversos microperforantes. Un gran número de foraminíferos presenta agujeros redondos microscópicos (de diámetro entre 1 y $60 \mu \mathrm{m}$ ), y concavidades redondeadas (de diámetro externo $25 \times 40 \mu \mathrm{m}$ ) sobre la superficie que pertenecen, respectivamente, a las icnoespecies Oichnus simplex Bromley, 1981 y Fossichnus solus Nielsen et al., 2003. Estas trazas aparecen justamente en los caparazones de foraminíferos que han estado fuertemente infestados por cianobacterias, algas y hongos microendolíticos, y sugieren un comportamiento etológico comparable entre la icnoespecie de Fossichnus y Oichnus y los euendolitos microbianos que se ascriben a taxones biológicos individuales. La mayor presencia de $F$. solus y $O$. simplex en los caparazones 
processes seem to be related to the $\mathrm{Mg} / \mathrm{Ca}$ ratio, as well as to morphological structures of the taxa.

Keywords: Microbioerosion traces, benthic foraminifera, environmental control.

\section{INTRODUCTION}

Microscopic round holes and roundish concavities on benthic foraminifera tests have long been described in recent and fossil marine environments (e.g., Sliter, 1971; Bromley, 1981, 2004; Arnold et al., 1985; Shroba, 1993; Hallock \& Talge, 1994; Nielsen, 1999, 2002; Nielsen \& Nielsen, 2001; Nielsen et al., 2003; Blissett \& Plickerill, 2007). According to Ekdale (1985) and Nielsen (1998, 1999), the majority of the microscopic traces can be interpreted as evidence of the predation of the foraminifera by unknown predators. The discussion of bioerosional structures in terms of the biological identification of tracemakers, the relationship between microbores and their biogenic substrates, and environmental control, plays an increasingly major role in geobiological research. Many trace fossils are very poorly known or understood, and therefore provide limited biological information. An organism is already able to produce more than one tracetype, while, conversely, similar traces may be produced by different organisms (Bromley, 2004).

The ichnological traces that are generally produced by unknown organisms have been interpreted as predatory activity and habitat ecospaces. According to Tapanila (2008), the endolithic lifestyle has the selective advantage of existing in a hard domicile that is secure from physical and biological stresses.

According to Glaub \& Vogel (2004) and Glaub et al. (2007), microbial euendoliths, which are defined by their microscopic size $(<100 \mu \mathrm{m}$ tunnel diameter), are a diversified group that includes prokaryotic and eukaryotic organisms.

A major infestation by microbial euendoliths (cyanobacteria, chlorophyceans, fungi) in foraminiferal tests has been revealed by SEM images. Along with the chemical composition of the hard substrates (benthic foraminifera), Cherchi et al. (2012) also demonstrated that the $\mathrm{Mg}$ content in calcareous tests can significantly influence the carbonate dissolution induced by the bioerosional process.

The aim of the current contribution is to investigate of the peculiar microscopic circular holes and cavities penetrating the modern living benthic foraminifera tests (Rose Bengal stained) taken from the coastal area of Portovesme-Portoscuso (south-western Sardinia, Italy, aporcelanados de $\mathrm{Mg}$ alto frente a los hialinos de $\mathrm{Mg}$ bajo revela que los procesos bioerosivos parecen estar relacionados con la relación $\mathrm{Mg} / \mathrm{Ca}$, así como con las estructuras morfológicas de los taxones.

Palabras clave: Trazas microbioerosivas, foraminíferos bentónicos, control ambiental.
Fig. 1), which is very polluted by heavy metals and the industrial release of $\mathrm{CO}_{2}$ (Schintu \& Degetto, 1999; Cherchi et al., 2009; Buosi et al., 2013). Control of the environmental conditions, which are: a) seriously compromised by anthropogenic activity when compared with the extensive microeuendolith development; and b) related to carbonate dissolution, has already been highlighted (De Giudici et al., 2013).

The ichnogenus Oichnus Bromley, 1981 is known to have been present from the late Precambrian (Bengtson \& Zhao, 1992) to recent times. In various fossil and recent biological hosts, multiple infestations with a range of morphologies of small to microscopic round holes, which are referable to Oichnus ispp., have been documented by several authors (Bromley, 1981, 1993; Nielsen \& Nielsen, 2001; Wilson \& Palmer, 2001; Donovan \& Jagt, 2002; Taylor \& Wilson, 2002; Blissett \& Pickerill, 2007; Neumann \& Wisshak, 2009). Nielsen \& Nielsen (2001), in particular, provided an ichnotaxonomic revision of this taxon.

Oichnus simplex Bromley, 1981 is known from the Maastrichtian (Donovan \& Jagt, 2002), and has also been found in the middle Eocene (Blissett \& Pickerill, 2007) and the Pliocene-late Holocene (Nielsen \& Nielsen, 2001), as well as in recent hard (organic -mainly- and inorganic) substrates (Shroba, 1993).

Fossichnus solus Nielsen et al., 2003 has been reported from the middle Eocene (Blissett \& Pickerill, 2007). Shroba (1993, fig. 7), meanwhile, has illustrated a specimen from recent foraminiferal tests belonging to this ichnospecies. For further information on the use of binominal names for modern traces in relation to the International Code of Zoological Nomenclature refer Nielsen \& Nielsen (2001), Nielsen et al. (2003) and Bertling et al. (2006).

\section{STUDY AREA}

The south-western coast of Sardinia is characterized by a relatively confined shallow shelf that slopes gently down to deeper water environments (Fig. 1). The bottom sediments are comprised of sandy submerged beach (PleistoceneHolocene in age), while Oligo-Miocene calcalkaline volcanics crop out north of the sampling area. This area has been under major anthropogenic pressure since the 
1960s, when the Portoscuso-Portovesme district began to develop and expand its activities.

The Portovesme Harbour, which was built in 1870 to ship ores (zinc blend, galena and pyrite) from the historical mines of the Sulcis-Iglesiente district, received major inputs from industrial discharge until a few decades

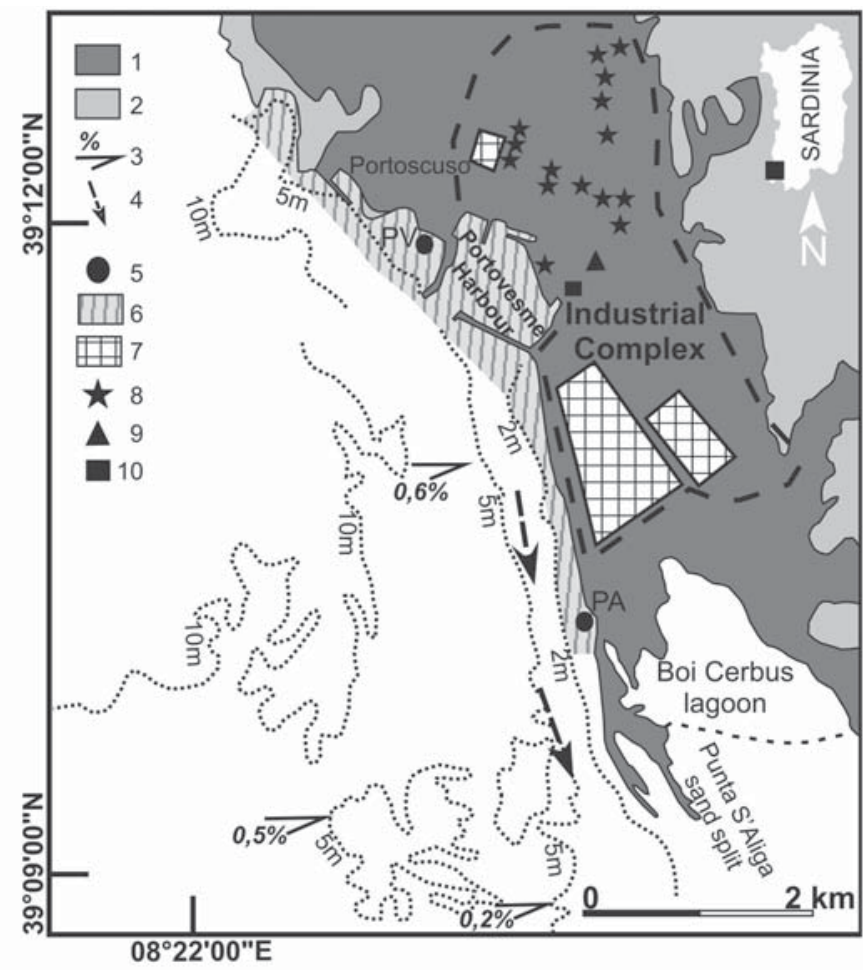

Figure 1. Study area, location of sampling stations (Portovesme - PV, Punta S'Aliga - PA) and industrial complex of Portoscuso (SW Sardinia). 1) Alluvial deposits (Pleistocene-Holocene); 2) volcanics (OligoMiocene); 3) seabottom slope (\%) from shoreline to $5 \mathrm{~m}$ isobath; 4) longshore drift; 5) sampling stations; 6) sampling area; 7) red mud dumps; 8) chimneys; 9) lead-zinc smelter; 10) electric power plant (modified from Cherchi et al., 2012).

ago. Chemical analyses of marine sediments from four cores collected in the Portovesme Harbour that faces the industrial complex revealed high concentrations of $\mathrm{Hg}$ (up to $50 \mathrm{mg} \mathrm{kg}^{-1}$ ), $\mathrm{Cd}$ (up to $120 \mathrm{mg} \mathrm{kg}^{-1}$ ), $\mathrm{Pb}$ (up to $20 \mathrm{mg}$ $\mathrm{kg}^{-1}$ ) and $\mathrm{Zn}$ (up to $70 \mathrm{mg} \mathrm{kg}{ }^{-1}$ ) in the upper $2 \mathrm{~cm}$. Metal concentrations fall with an increase in the distance between the sampling stations and the industrial effluent discharge point (Schintu \& Degetto, 1999). This large industrial development has had a considerable environmental impact, meaning that the district has been declared an environmental hazard (D.P.C.M. - Prime Ministerial decree, 23 April 1993) because of several recognized "danger centres" (ARPAS, 2007). Emissions into the atmosphere and all of the surrounding environments have been estimated annually to be 65,000 tons of SOx, 4,000 tons of dust, 10 tons of $\mathrm{Pb}$ and 100 tons of Fe (Gazzetta Ufficiale della Repubblica Italiana, 1993). The large electric power stations and the numerous chimneys also produce significant amounts of $\mathrm{CO}_{2}$ (Schintu \& Degetto, 1999; Bettini \& Zanin, 2002). The industrial complex, which was developed on a coastal alluvial plain, includes factories producing aluminium from bauxite and a leadzinc smelter producing $\mathrm{Pb}, \mathrm{Zn}, \mathrm{Cd}, \mathrm{H}_{2} \mathrm{SO}_{4}$ and $\mathrm{Hg}$ from $\mathrm{Pb}$ and $\mathrm{Zn}$ mixed sulphides. A large dump of red muds (seawater-neutralised bauxite refinery residues) is located near the coast (Fig. 1).

\section{MATERIALS AND METHODS}

For this preliminary study on ichnodiversity in a polluted area, we have selected particularly 4 samples coming from the two highest polluted stations (PV and PA) collected in the inner shelf facing the Portoscuso-Portovesme industrial complex (Fig. 1), where the sea is less than $2 \mathrm{~m}$ deep. The sampled sediments came from the upper 1-2 cm below the water column. The benthic foraminifera assemblages and their biodiversity indices, as well the geochemical characterization of the investigated area, were the subject of an earlier paper, where the foraminiferal response to heavy metal pollution was assessed (Cherchi et al., 2009). The living foraminiferal assemblages for PV and PA stations are reported in Table 1 with the incidence of the Oichnus and Fossichnus borings. During the sampling period in July 2006, the water temperature ranged between 27.7 and $30.6^{\circ} \mathrm{C}$.

In laboratory, the sediment samples were washed through a set of nested sieves $(63,125,180,250 \mu \mathrm{m})$. Benthic foraminifera from $5 \mathrm{cc}$ of the $>125 \mu \mathrm{m}$ size fraction (a - medium-grained) and 5cc of the $<125 \mu \mathrm{m}$ size fraction ( $b$ - fine-grained) were then picked, counted and classified.

Environmental scanning electron microscopy (ESEM) images revealed an extensive infestation of the foraminiferal tests by boring microflora communities (Cherchi et al., 2012). The bioerosional traces were analyzed via ESEM (QUANTA 200, FEI, Hillsboro, Oregon, and partly with EVOLS15, ZEISS). To estimate quantitatively the impact of the microbial borings on the foraminifera and selective bioerosion on high-Mg and low-Mg foraminiferal tests, 300 specimens were picked randomly from the $>63 \mu \mathrm{m}$ fraction of each sample and observed with a scanning electron microscope. A total of 1200 living foraminifera (Rose Bengal stained) were examined.

All of the samples are housed in the Chemical and Geological Department of the University of Cagliari (Italy). 
Table 1. Relative abundance of foraminiferal species from PV and PA stations with the absolute and relative abundance of the Oichnus and Fossichnus borings.

\begin{tabular}{|c|c|c|c|c|c|c|c|}
\hline & \multicolumn{3}{|c|}{$\mathbf{P V}$} & \multicolumn{4}{|c|}{$\mathbf{P A}$} \\
\hline & \multirow{2}{*}{$\begin{array}{l}\text { Foram } \\
\%\end{array}$} & \multicolumn{2}{|c|}{ O. simplex } & \multirow{3}{*}{$\begin{array}{l}\text { Foram } \\
\% \\
1.14\end{array}$} & \multicolumn{2}{|c|}{ O. simplex } & F. solus \\
\hline & & & $\%$ & & & $\%$ & n. $\%$ \\
\hline Adelosina cliarensis (Heron-Allen \& Earland) & 1.41 & 8 & 12.31 & & 43 & 26.88 & - \\
\hline Adelosina mediterranensis (Le Calvez) & 0.70 & 6 & 9.23 & - & - & - & - \\
\hline Ammonia beccarii (Linné) & 5.16 & - & - & 3.69 & 2 & 1.25 & - \\
\hline Ammonia parkinsoniana (d'Orbigny) & 1.17 & - & - & 1.70 & - & - & - \\
\hline Asterigerinata mamilla (Williamson) & 2.35 & - & - & 2.27 & - & - & \\
\hline Cibicides pseudolobatulus Perelis and Reiss & 11.50 & - & - & 4.26 & - & - & - \\
\hline Cyclocibicides vermiculatus (d'Orbigny) & 0.94 & - & - & 0.28 & - & - & \\
\hline Cycloforina contorta (d’Orbigny) & 0.94 & - & - & - & - & - & - \\
\hline Elphidium crispum (Linné) & 11.50 & - & - & 15.06 & 7 & 4.38 & - \\
\hline Haynesina depressula (Walker \& Jacob) & 1.41 & - & - & - & - & - & - \\
\hline Haynesina germanica $($ Ehrenberg) & 1.17 & - & - & - & - & - & - \\
\hline Lobatula lobatula (Walker \& Jacob) & 11.74 & 3 & 4.62 & 8.24 & 9 & 5.63 & - \\
\hline Miliolinella labiosa (d'Orbigny) & 0.23 & - & - & - & - & - & - \\
\hline Peneroplis pertusus (Forskål) & 7.98 & 8 & 12.31 & 5.40 & 4 & 2.50 & - \\
\hline Peneroplis planatus (Fichtel \& Moll) & 1.88 & 2 & 3.08 & - & - & - & - \\
\hline Pseudotriloculina laevigata (d'Orbigny) & 4.93 & 9 & 13.85 & 11.65 & 42 & 26.25 & - \\
\hline Pseudotriloculina oblonga (Montagu) & 0.47 & - & - & 1.99 & 3 & 1.88 & - \\
\hline Quinqueloculina seminula (Linnaeus, 1758) & 7.04 & 8 & 12.31 & 9.38 & 15 & 9.38 & - \\
\hline Quinqueloculina ungeriana d'Orbigny & 5.63 & - & - & 15.34 & - & - & - \\
\hline Rosalina bradyi Cushman & 6.10 & 8 & 12.31 & 6.25 & 14 & 8.75 & - \\
\hline Rosalina floridensis (Cushman) & 9.62 & 11 & 16.92 & 8.81 & 17 & 10.63 & - \\
\hline Triloculina schreiberiana d'Orbigny & 3.29 & 2 & 3.08 & 1.70 & 1 & 0.63 & 100 \\
\hline \multirow[t]{2}{*}{ Triloculina tricarinata d'Orbigny } & 2.82 & - & - & 2.84 & 3 & 1.88 & - \\
\hline & 100 & 65 & 100 & 100 & 160 & 100 & 100 \\
\hline
\end{tabular}

\section{SYSTEMATIC ICHNOLOGY} 2003

Ichnogenus Fossichnus Nielsen, Nielsen \& Bromley,

Type ichnospecies. Fossichnus solus Nielsen, Nielsen \& Bromley, 2003.

Diagnosis. "Biogenic concavity characterized by a circular to oval groove. Outer border conforms with inner border, both sharp in outline. Parts of the groove may penetrate through the substrate. Situated in skeletal substrates" (Nielsen et al., 2003).

Fossichnus solus Nielsen, Nielsen \& Bromley 2003. (Figs 2, 3)

1993 Boring; Shroba, p. 262, fig. 7.

2003 Fossichnus solus isp. nov.; Nielsen, Nielsen \& Bromley, p. 3, figs. 1-3.
2007 Fossichnus solus; Blissett \& Pickerill, p. 86, fig. 4.

Material. Seven specimens randomly distributed in a porcelanaceous foraminiferal test (Triloculina schreiberiana), coming from PA sample (Fig. 1).

Diagnosis. As for ichnogenus (Nielsen et al., 2003).

Description. Concavity constituted by a hollow ring around its circumference. The shortest diameter of the outer edge is $25 \mu \mathrm{m}$, with the longest diameter being about $40 \mu \mathrm{m}$. The outline of the ring groove is irregular, with a minimum and maximum thickness of about 3:10 $\mu \mathrm{m}$ respectively. In our material, this enigmatic trace appears as both a solitary concavity with a hollow rough ring around its circumference and as two adjacent, connected oval concavities separating inside an egg-shaped fragment of the residual calcareous test of foraminifer (Fig. 2). 


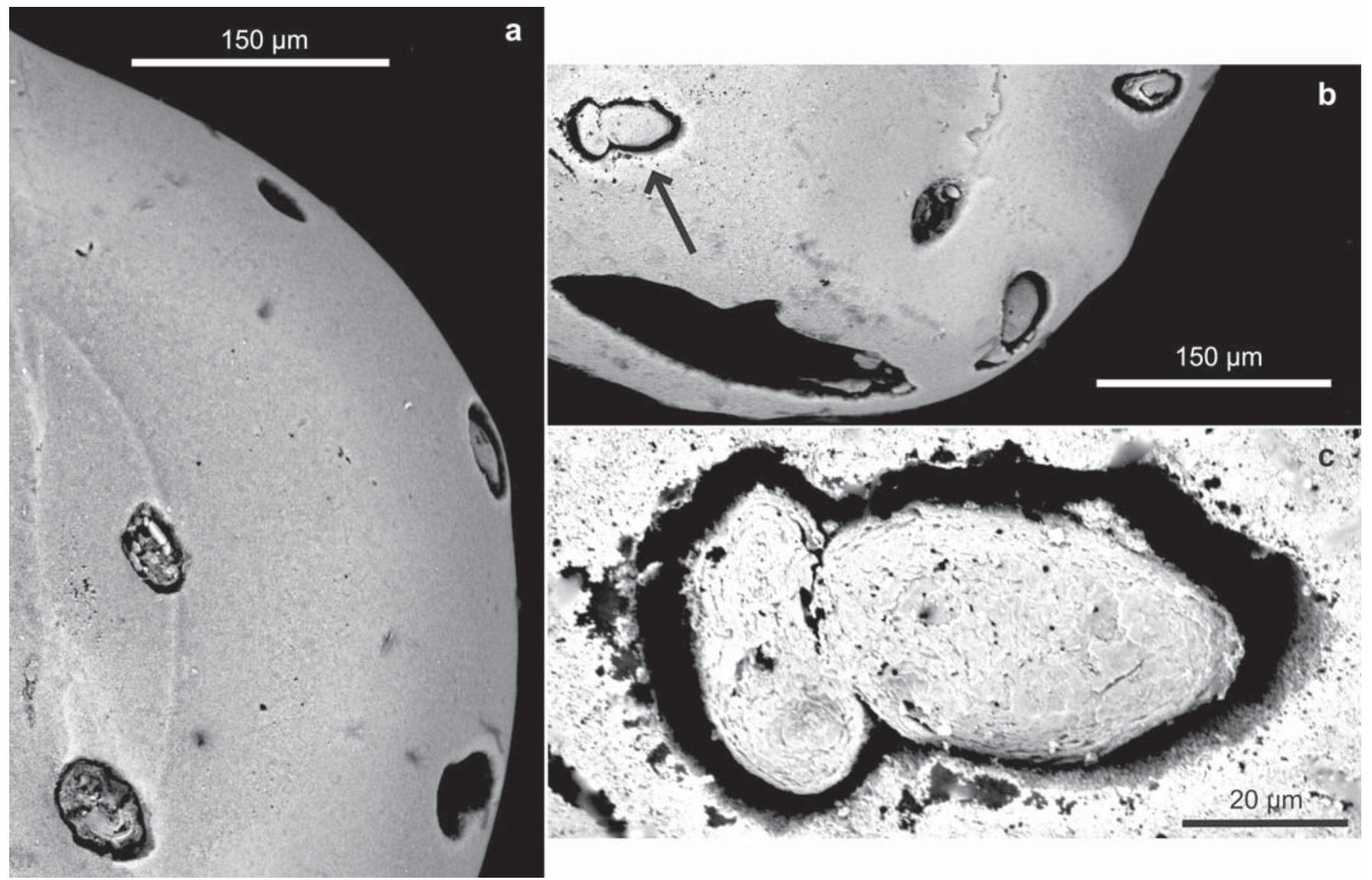

Figure 2. SEM images of the surface bioerosion of porcelanaceous imperforate foraminifera (Triloculina schreiberiana) from the PA station (in Fig. 1). a) Several rounded concavities belonging to Fossichnus solus Nielsen et al., 2003. b) Several specimens of $F$. solus. c) Close-up of $F$. solus showing a rounded irregular cavity constituted of a hollow ring around its circumference and composed of two adjacent combined concavities.

Remarks. In the ichnotaxonomic description by Nielsen et al. (2003), F. solus is characterized by a circular to an oval concavity. According to Nielsen et al. (2003; fig. 4), these concavities can sometimes appear as randomly repeated solitary bioerosive structures.

The SEM image in Fig. 2c reveals a peculiar morphotextural pattern in damaged test of Triloculina, infested by $F$. solus, exhibiting at a high magnification (Fig. 3) a microlayering convolute fabric around the nucleus that cannot be related to the primary pattern of the Miliolida. In our opinion, this convolute fabric could depict a micritisation process by cyanobacterial activity.

According to Nielsen et al. (2003), Fossichnus solus seems to be part of a developmental sequence where the end member is Oichnus simplex. The bioerosional structures of our material are similar to those of the F. solus type-material, and do not thus contribute to a solution of the taxomonic question.

Ichnogenus Oichnus Bromley, 1981

Type ichnospecies. Oichnus simplex Bromley, 1981.
Diagnosis. "Circular to subcircular holes of biogenic origin bored into hard substrates. The hole may pass right through the substrate as a penetration, where the substrate is a thin shell; or end within the substrate as a shallow to deep depression or short, subcylindrical pit" (Bromley, 1981; emended by Nielsen \& Nielsen, 2001).

\section{Oichnus simplex Bromley, 1981}

(Figs 4, 5)

1981 Oichnus simplex isp. nov.; Bromley, p. 60, pl. 2 figs. 2-5, pl. 3 fig. 3.

1990 unnamed structures; Samanta et al., pl. 8 fig. 1A, pl. 10 fig. 28.

1998 Oichnus simplex; Pickerill et al., p. 27, fig. 9 B, D.

2001 Oichnus simplex; Nielsen \& Nielsen, p. 103, figs. 1A-B, 5.

2002 Oichnus simplex; Donovan \& Jagt, p. 72, fig. 4A. 2002 Oichnus simplex; Pickerill et al., p. 112, fig. 3D. 2003 Oichnus simplex; Dávid, pl. 1 fig. 2.

2006 Cylindrical holes; pars Oichnus ispp.; Görmüş \& Nielsen, fig. 3. 


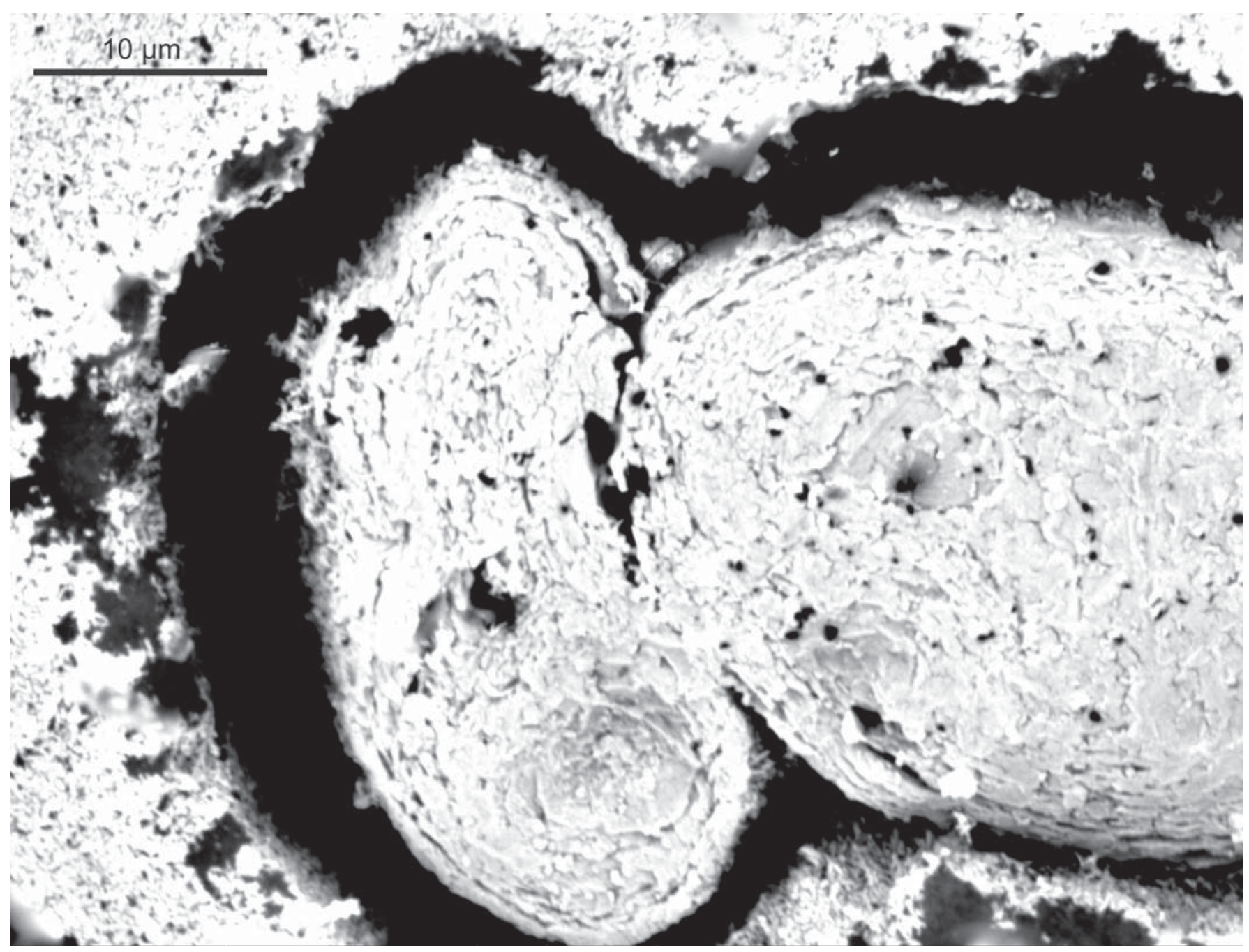

Figure 3. Enlargement of Figure 2c. See 2 adjacent, connected bodies in the cavity, each with a different shape: ovoid on the right side and ellipsoidal on the left. The ellipsoidal body shows a convolute microlayering fabric around a nucleus, depicting a micritic process in the wall of the miliolid test.

2007 Oichnus simplex; Blissett \& Pickerill, p. 90, pl. 3 fig. 6.

2007 Oichnus simplex; Gibert et al., p. 791, fig. 9D.

2009 Oichnus simplex; Sengupta \& Nielsen, p. 82, figs. 3A-F.

Material. More than 200 specimens randomly distributed above all in porcelanaceous (Quinqueloculina, Pseudotriloculina) and, less frequently, in hyaline foraminiferal tests (Rosalina), coming from PV and PA samples (Fig. 1).

Diagnosis. "Oichnus having a simple cylindrical or subcylindrical form, an axis more or less perpendicular to the substrate surface. Where the substrate is not penetrated right through, the distal end is flattened hemispherical" (Bromley, 1981, p. 60).
Description. Microscopic circular to oval holes with long axes that are perpendicular or "uncommonly" slightly oblique to the substrate surface. The diameters of the holes range from 1 to $60 \mu \mathrm{m}$ ( $15 \mu \mathrm{m}$ mean diameter, 9.26 standard deviation, $10 \mu \mathrm{m}$ median diameter, $30 \%$ of the traces have a 6-10 $\mu \mathrm{m}$ size diameter). Figure 6 sets out the reported diameters and percentages of $O$. simplex that occurred in our material. The edges of the holes generally have an irregular scratching (Fig. 4).

Remarks. Elliptical holes have sometimes been observed (cfr. Group B: oval to sub-oval holes in Nielsen, 1999). The surfaces of several miliolid tests exhibit widespread bioerosional traces depicted by both larger and microscopic holes (Fig. 4). Figure 5a shows undetermined filaments (belonging to e.g., cyanobacteria, algae, fungi) boring and/or colonizing previous microscopic circular 

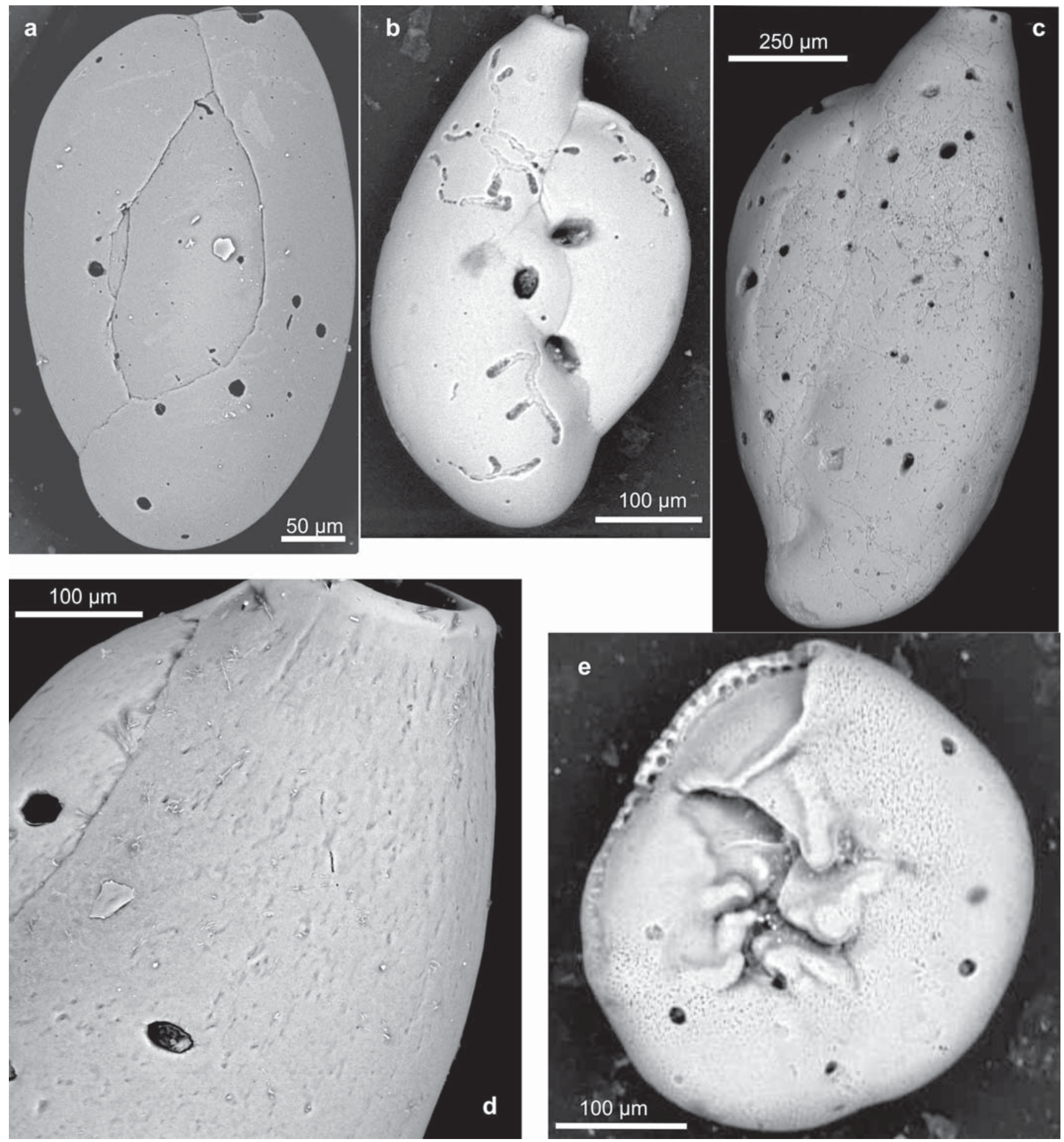

Figure 4. SEM images of surfaces of benthic foraminifera showing widespread bioerosional microscopic traces belonging to Oichnus simplex Bromley, 1981 (a-e). See the highest circular trace diameter in (b), where there are recognizable, undetermined microborings (arrows). O. simplex in imperforate porcelanaceous tests belonging to a) Quinqueloculina seminula; b and c) Adelosina sp.; d) Triloculina sp.; and e) O. simplex in a perforated hyaline test belonging to Rosalina sp.

holes identified as to $O$. simplex. The diameter of the microscopic holes (1-2 $\mu \mathrm{m})$ is consistent with the diameter of the filaments. In Quinqueloculina ungeriana (Fig. 5b), undetermined tubular borings (3-5 $\mu \mathrm{m}$ in diameter) are parallel to the surface of the test and penetrate into microscopic circular holes (cf. O. simplex) with the same diameter. 


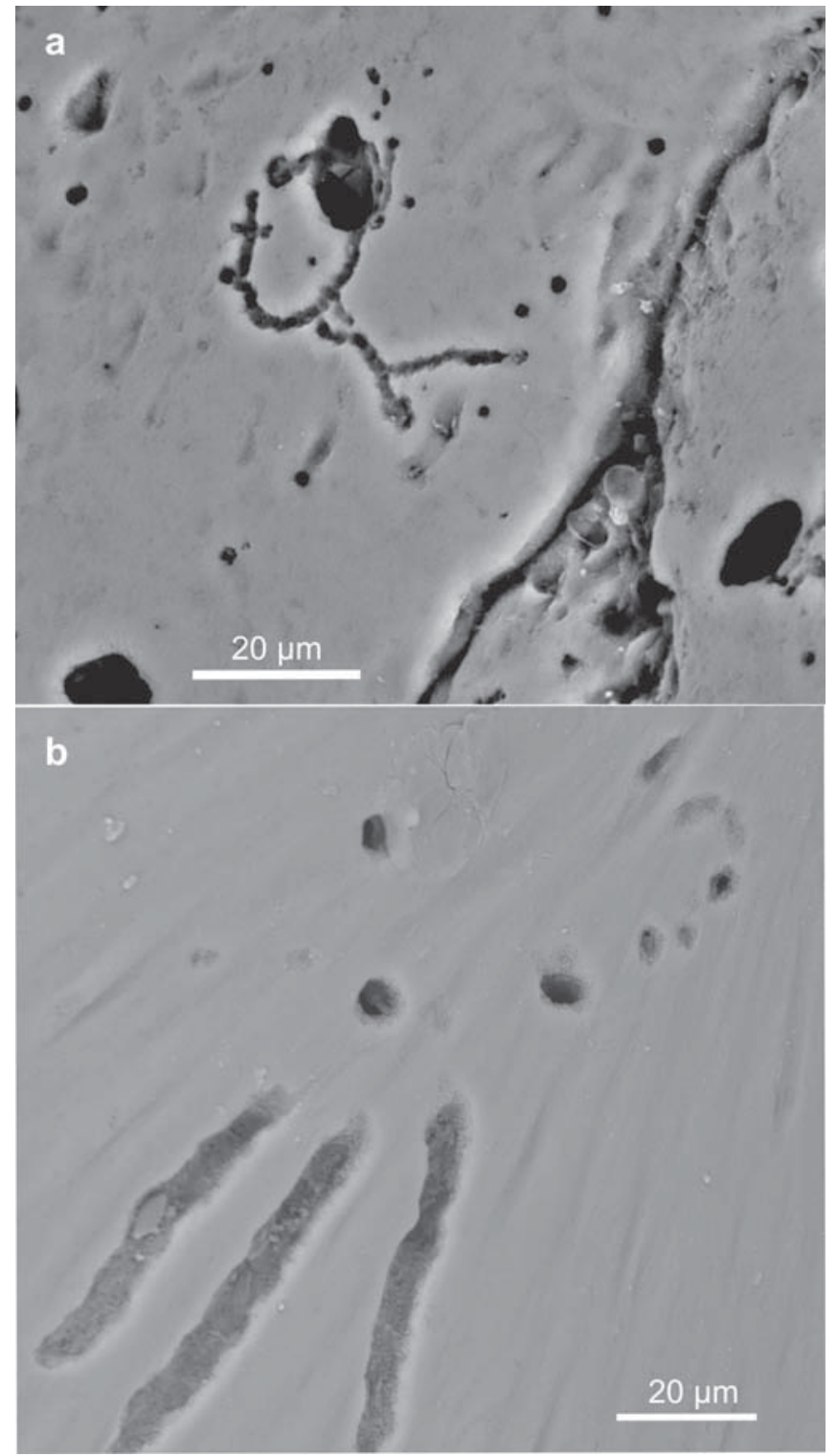

Figure 5. SEM images of multi-diversified bioerosional traces in miliolid tests. a) Large and microscopic penetrating holes belonging to Oichnus simplex and overlying indeterminate borings that could be responsible for the smaller microscopic holes. b) Tubular borings, 3-5 $\mu \mathrm{m}$ in diameter, running parallel to the surface of the test and penetrating into the wall of Quinqueloculina. See microscopic circular holes showing irregular scratching edges.

\section{RESULTS AND DISCUSSION}

Traces produced by boring microflora in benthic calcareous foraminifera, sampled from a coastal area neighbouring the Portoscuso-Portovesme industrial complex, have previously been revealed by Cherchi et al. (2012). A total of 23 benthic foraminiferal species belonging to 15 genera were identified in the living assemblages. The foraminiferal biocoenosis is largely dominated by Quinqueloculina ungeriana, Elphidium crispum and Lobatula lobatula (Table 1). Species Richness and the number of foraminiferal specimens show a decrease in PA station related to an increasing in heavy metal fluxes as evidenced in previous study (Cherchi et al., 2009).

Cherchi et al. (2012) reported, for the whole sampled area of Portoscuso-Portovesme, ESEM images of foraminiferal surface tests and epoxy resin casts with evidenced widespread and intense bioerosion processes produced by diversified phototrophic (cyanobacteria, chlorophyta) and heterotrophic (fungi) organisms (Table 2). The $>63$ $\mu \mathrm{m}$ sediment fractions had exhibited a large number of microscopic round holes identified as Oichnus simplex, and several circular grooves identified as Fossichnus solus on foraminiferal tests. Figure 6 sets out the size and percentage of $O$. simplex in the high-Mg porcelanaceous foraminifera (miliolids). Oichnus simplex is very frequent, more than 200 specimens, are randomly distributed above all in porcelanaceous (Quinqueloculina, Pseudotriloculina) and, less frequently, in hyaline foraminiferal tests (Rosalina), coming from PV and PA samples. Whereas, 7 specimens randomly distributed of $F$. solus have been found only in a porcelanaceous foraminiferal test (Triloculina schreiberiana), coming from PA sample (Table 1).

Foraminiferal tests examined in the sampling area, $50 \%$ exhibited evidence of borings. Among the infested foraminifera, $60 \%$ presented high-Mg porcelanaceous tests and $40 \%$ low-Mg hyaline tests. The number of infested tests is twice as high in the porcelanaceous than in the hyaline foraminifera, and the proportion of infested tests is two to three times higher in the PA station located south of the Portovesme-Portoscuso area (Cherchi et al., 2012; fig. 10). The sampled area had the lowest seawater $\mathrm{pH}$ and stressed environmental conditions. Climatic conditions, chemical analyses of the sediment-water interface, geochemical characterization and the biodiversity indices of benthic foraminifera (substrate of the borings) were reported in Cherchi et al. (2009). The bioerosional processes in the foraminiferal tests increased from north to south in the sampling area, with the highest values $(70 \%)$ in the PA station $(59.7 \%$ in the hyaline and $80.3 \%$ in porcelanaceous specimens, respectively).

This coastal environment highlights the exceptional development of bioerosional processes evident by a high ichnodiversity, while in the other coastal environments of Sardinia, at the same depths, bioerosional traces are generally very rare. In our opinion, the source of this large microbial infestation can be related to serious environmental decay due to anthropogenic activity.

On both surfaces of the benthic foraminifera tests from some of the sampling sites previous analysed for Cherchi et al. (2012), we have recognized microscopic round holes identified as Oichnus simplex and Fossichnus solus. The very microscopic $O$. simplex have a range from about 1 to $60 \mu \mathrm{m}$ in diameter. These bioerosional drill-holes 
Table 2. Microborings distribution in the sampling area and their relative abundance $(++$ very common, + common, $=$ rare $)($ modified from Cherchi et al., 2012).

\begin{tabular}{|c|c|c|}
\hline \multicolumn{2}{|c|}{ Foraminifera substrata } & \multirow[t]{2}{*}{ Abundance } \\
\hline Borings & $\begin{array}{r}\text { Trace-makers } \\
\end{array}$ & \\
\hline Eurigonum nodosum Schmidt & Mastigocoleus testarum Lagerhein (cyanophyte) & ++ \\
\hline Fascichnus cf. dactylus (Radtke) & Hyella caespitosa Bornet and Flahault (cyanophyte) & ++ \\
\hline Scolecia filosa Radtke & $\begin{array}{l}\text { Plectonema terebrans Bornet and Flahault } \\
\text { (cyanophyte) }\end{array}$ & ++ \\
\hline Scolecia meandria Radtke & $\begin{array}{l}\text { "vermicular borings" (Zeff and Perkins, 1979) } \\
\text { (cyanophyte) }\end{array}$ & + \\
\hline ? Planobola macrogota Schmidt & cyanobacterium? alga? & + \\
\hline ? Cavernula pediculata Radtke & $\begin{array}{l}\text { Gomontia polyrhiza (Lagerhein) Bornet and Flahault } \\
\text { (chlorophyte) }\end{array}$ & + \\
\hline Ichnoreticulina elegans (Radtke) & Ostreobium quekettii Bornet and Flahault (chlorophyte) & ++ \\
\hline Rhopalia catenata Radtke & Phaeophila dendroides Cronan (chlorophyte) & $=$ \\
\hline Orthogonum fusiferum Radtke & Ostracoblabe implexa Bornet and Flahault (fungus) & + \\
\hline Orthogonum lineare Glaub & ? fungus & + \\
\hline \multicolumn{2}{|l|}{$\begin{array}{l}\text { Orthogonum isp. (Form } 1 \text { in Wisshak } \\
\text { et al., 2005) }\end{array}$} & $=$ \\
\hline \multirow[t]{2}{*}{ Saccomorpha clava Radtke } & Dodgella priscus Zebrowski (fungus) & ++ \\
\hline & Coccoid bacteria & + \\
\hline
\end{tabular}

that are present on several foraminiferal taxa have been calculated quantitatively. The greater occurrence of $O$. simplex in the high-Mg porcelanaceous imperforate tests (Quinqueloculina, Pseudotriloculina) than in the low-Mg bilamellar hyaline perforate tests (Rosalina) is less frequent (about 4:1 ratio), and confirms that carbonate dissolution depends largely on the $\mathrm{Mg}$ content as well as the morphostructural pattern of the taxa (Cherchi et al., 2012; De Giudici et al., 2013). Oichnus simplex has been found in almost all of the analyzed areas, but is more abundant in the PA and PV stations. In Figures 2 to 5, we set out evidence of several microscopic circular to subcircular holes bored perpendicularly into the foraminifera tests. Fossichnus solus in our material were found exclusively in the high-Mg porcelanaceous specimen (Triloculina schreiberiana) and only from the PA station (Fig. 1). This confirms previous studies (Cherchi et al., 2012; De Giudici et al., 2013) on the biogenic carbonate dissolution controlled by environmental parameters. According to Nielsen et al. (2003), the distribution of F. solus seems to depend on environmental conditions.
The microscopic $O$. simplex that deeply penetrate the foraminiferal tests, which are produced by unknown prokaryotic or eukaryotic microorganisms (including boring microflora?; see Figs 5a-b), can seemingly be interpreted as predatory traces that are searching organic matter as a source of food. The presence of organic layers in the porcelanaceous and hyaline foraminifera tests proves the bioerosional activity. The porcelanaceous wall consists of a thick layer of high-Mg calcite needles, with relatively large interstices filled with organic matter. The needles are randomly arranged and coated inside with an inner organic lining and outside by the outer organic layer (Towe \& Cifelli, 1967; Hemleben et al., 1986; Debenay et al., 2000a). In the bilamellar hyaline perforate group, the wall is comprised of carbonate layers separated by an organic median layer (Towe \& Cifelli, 1967; Hansen \& Reiss, 1971; Hottinger, 1978, 2000; Hansen, 1999; Debenay et al., 2000b). Our data support that these microscopic traces may be interpreted as evidence of predators in search of organic matter in the foraminiferal test (inner and outside organic layer; Towe \& Cifelli, 1967; Hansel \& Reiss, 1971; Hemleben et al., 1986; Hansen, 1999; Debenay et 
al., 2000a, b; Debenay, 2012), confirming the previous observations of Ekdale (1985) and Nielsen (1998, 1999).

According to Bromley (2004), Oichnus can be produced by a wide range of trace-maker organisms. Millimetric round drill-holes that are considered to be as morphologically distinguishable as $O$. simplex are dominantly produced today by predatory Muricacea gastropods. Meanwhile, according to Wisshak (2006), microboring bioerosive agent related to the ichnogenus Oichnus with trace diameters $<100 \mu \mathrm{m}$ can be attributed to the chemical boring of the flatworms Pseudostylachus. Nielsen \& Nielsen (2001) reported that Oichnus is among the most common borings, and the size of the borings is probably a reflection of the size of the trace-makers. If the size of a trace-maker (body, pedicle or mouth parts) is reflected in the size of the trace on the foraminiferal test, many adult predatory gastropods are too large to be likely trace-makers. The juveniles of these organisms may have the right size of body or physiological features to be candidates, but owing to the morphology of the bioerosion traces can probably also be disregarded (Nielsen \& Nielsen, 2001). The traces described in this work are very small in size, and their diameter range is between 1 and $60 \mu \mathrm{m}(30 \%$ of the holes have a $6-10 \mu \mathrm{m}$ size diameter). Bearing in mind the small size of our traces, we cannot exclude the possibility that the trace-maker could also be undetermined microbial endoliths (cyanobacteria, other bacteria, algae and fungi). The diameter of the microscopic holes (1-2 $\mu \mathrm{m}$, Fig. 5a) is consistent with the diameter of the ramified filamentous traces $(1-2 \mu \mathrm{m})$. As well as the traces observed in Quinqueloculina ungeriana (Fig. $5 b$ ), there are tubular borings (3-5 $\mu \mathrm{m}$ in diameter) running parallel to the surface of the test and penetrating into the wall of the foraminifera, suggesting a microbial trace-maker.

In our material, the $F$. solus appears to be enigmatic, because we have 2 adjacent connected concavities (Figs 2c, 3). The SEM image (Fig. 3) shows a peculiar morphological structure, which could be interpreted as a hypothetical, more biogenic, complex that exhibits a microlayering convolute fabric. This test microstructure cannot be related to the textural pattern of Miliolida, and could be associated with cyanobacterial micritisation. In fact, the wall is opaque, with a randomly arranged middle layer of crystal needles enclosed between the thin inner and outer well-ordered veneers. According to Debenay (2012), the porcelanaceous test surface generally appears in SEM images to be composed of rhombohedral platelets that cover irregularly arranged calcitic needles.

Nielsen et al. (2003) reported that the feature used needed morphology much like a hollow tube to produce such traces. Fossichnus solus seems to be an early stage of a development sequence, where the end member could be Oichnus simplex, which penetrates the test to search the organic matter of the foraminiferal test (trophic strategies).
However, most specimens of $F$. solus have not been transformed into $O$. simplex. These authors concluded that the penetration appears to have been inefficient, meaning that predatory behaviour is less likely and $F$. solus is more likely to be interpreted as an attachment scar formed by an unknown tracemaker. The bioerosional structures of our material are similar to those of the type-material of $F$. solus, and do not thus contribute to a solution to the taxonomic problem.

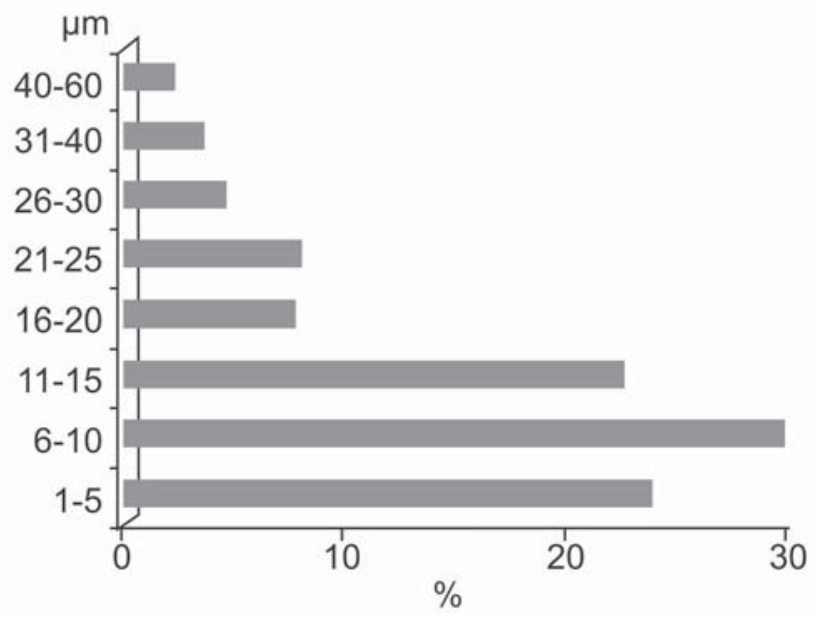

Figure 6. Size and percentage of Oichnus simplex in the high$\mathrm{Mg}$ porcelanaceous foraminifera (miliolids). The diameter of the holes varies between 1-60 $\mu \mathrm{m}(30 \%$ between $6-10 \mu \mathrm{m}, 23 \%$ between $1-5 \mu \mathrm{m}, 22 \%$ between 11-15 $\mu \mathrm{m})$

\section{CONCLUSIONS}

Samples collected at the same depth (about $2 \mathrm{~m}$ ) from a coastal area affected by serious industrial pollution reveal a great diversity of bioerosional traces in the benthic foraminifera. These traces are identified as produced by euendolithic cyanobacteria, algae and fungi (as described by Cherchi et al., 2012), and by unknown trace-makers producing microscopic round holes and curved cavities (sensu Bromley, 2004). The very small dimension of the boreholes penetrating the benthic foraminifera tests already infested by recognized boring microflora could be suggestive of the speculative hypothesis that these microscopic traces can also be produced by microbes, including bacteria, algae and fungi. Those traces can be interpreted as an ecological behaviour among marine microorganisms. This study corroborates the notion that bioerosional processes are greater in high-Mg than low-Mg foraminiferal tests and confirms our previous studies on the biogenic carbonate dissolution controlled by environmental parameters. 
The research topic is in its early stage; however, this paper is likely to inspire future bioerosion studies of polluted areas.

\section{ACKNOWLEDGEMENTS}

Authors gratefully acknowledge the Sardinia Regional Government for the financial support (P.O.R. Sardegna F.S.E. Operational Programme of the Autonomous Region of Sardinia, European Social Fund 2007-2013 - Axis IV Human Resources, Objective 1.3, Line of Activity 1.3.1 "Avviso di chiamata per il finanziamento di Assegni di Ricerca"). Likewise, authors warmly thank the reviewers Rosa Domènech (Barcelona, Spain) and Jan Kresten Nielsen (Stjoerdal, Norway) for their useful comments and suggestions. The latter has given very useful taxonomic comments.

\section{REFERENCES}

Agenzia Regionale per la Protezione dell'ambiente della Sardegna (ARPAS) 2007. Determinazione dei valori di fondo nelle matrici ambientali dell'area di Portoscuso (CI). Progetto operativo.

Arnold, A.J., D’Escrivan, F. \& Parker, W.C. 1985. Predation and avoidance responses in the foraminifera of the Galapagos hydrothermal mounds. Journal of Foraminiferal Research, 15, 38-42.

Bengtson, S. \& Zhao, Y. 1992. Predatorial borings in late Precambrian mineralized xoskeletons. Science, 257, 267-369.

Bertling, M., Braddy, S., Bromley, R.G., Demathieu, G.D., Genise, J., Mikuláš, R., Nielsen, J.K., Nielsen, K.S.S., Rindsberg, A., Schlirf, M. \& Uchman, A. 2006. Names for trace fossils: a uniform approach. Lethaia, 39, 265-286.

Bettini, V. \& Zannin, D. 2002. Portoscuso, la gassificazione della V.I.A.-Il Gassificatore Ati-Sulcis, le problematiche ambientali connesse al progetto. CUEN, Napoli, Italy.

Blissett, D.J. \& Pickerill, R.K. 2007. Systematic ichnology of microborings from the Cenozoic White Limestone Group, Jamaica, West Indies. Scripta Geologica, 134, 77-108.

Bromley, R.G. 1981. Concepts in ichnotaxonomy illustrated by small round holes in shells. Acta Geologica Hispanica, $16,55-64$.

Bromley, R.G. 1993. Predation habits of octopus past and present and a new ichnospecies, Oichnus ovalis. Bulletin of the Geological Society of Denmark, 40, 167-173.

Bromley, R.G. 2004. A stratigraphy of marine bioerosion. In: The Application of Ichnology to Palaeoenvironmental and Stratigraphic Analysis (ed. McIlroy, D.). Geological Society, London, Special Publications, 228, 455-479.
Buosi, C., Cherchi, A., Ibba, A., Marras, B., Marrucci, A. \& Schintu, M. 2013. Preliminary data on benthic foraminiferal assemblages and sedimentological characterisation from some polluted and unpolluted coastal areas of Sardinia (Italy). Bollettino della Società Paleontologica Italiana, 52, 35-44. doi: 10.4435/BSPI.2013.08.

Cherchi, A., Buosi, C., Zuddas, P. \& De Giudici, G. 2012. Bioerosion by microbial euendoliths in benthic foraminifera from heavy metal-polluted coastal environments of Portovesme (South-Western Sardinia, Italy). Biogeosciences, 9, 4607-4620.

Cherchi, A., Da Pelo, S., Ibba, A., Mana, D., Buosi, C. \& Floris, N. 2009. Benthic foraminifera response and geochemical characterization of the coastal environment surrounding the polluted industrial area of Portovesme (South-Western Sardinia, Italy). Marine Pollution Bulletin, 59, 281-296.

Dávid, Á. 2003. Bioeróziós nyomok, patológiás elváltozások és epizoák a Mátra Múzeum Wind gyári puhatestủinek mészvázain. Folia Historico Naturalia Musei Matraensis, 5-32.

Debenay, J.-P. 2012. A guide to 1,000 foraminifera from southwestern Pacific New Caledonia. IRD Edition, Marseille, Publications Scientifiques du Muséum, Paris.

Debenay, J.-P, Guillou, J.J., Geslin, E. \& Lesourd, M. 2000b. Crystallization of calcite in foraminiferal tests. Micropaleontology, 46, 87-94.

Debenay, J.-P., Guillou, J.J., Redois, F. \& Geslin, E. 2000a. Distribution trends of foraminiferal assemblages in paralic environments: a base for using foraminifera as early warning indicators of anthropic stress. In: Environmental Micropaleontology (ed. Martin, R.). Kluwer Academic/ Plenum Publishing Corporation, 39-67.

De Giudici, G., Buosi, C., Cherchi, A., Musu, E. \& Zuddas, P. 2013. Biomineralization processes in heavy metals polluted environments. Procedia Earth and Planetary Science, 7, 199-202.

Donovan, S.K. \& Jagt, W.M. 2002. Oichnus Bromley borings in the irregular echinoid Hemipneustes Agassiz from the type Maastrichtian (Upper Cretaceous, The Netherlands and Belgium). Ichnos, 9, 67-74.

Ekdale, A.A. 1985. Paleoecology of the marine endobenthos. Paleaegeography, Palaeoclimatology, Palaeoecology, 50, 63-81.

Gazzetta Ufficiale della Repubblica Italiana 1993. Piano di disinquinamento per il risanamento del territorio del Sulcis-Iglesiente, 190, 14 August 1993.

Gibert, J.M. de, Domènech, R. \& Martinell, J. 2007. Bioerosion in shell beds from the Pliocene Roussillon Basin, France: implications for the (macro) bioerosion ichnofacies model. Acta Paleontologica Polonica, 52, 783-798.

Glaub, I., Golubic, S., Gektidis, M., Radtke, G. \& Vogel, K. 2007. Microborings and microbial endoliths: geological implications. In: Trace fossils: concepts, problems, prospects (ed. Miller III, W.). Elsevier, Amsterdam, 368-381.

Glaub, I. \& Vogel, K. 2004. The stratigraphic record of microborings. Fossils and Strata, 51, 126-135. 
Görmüş, M. \& Nielsen, J.K. 2006. Borings in larger benthic foraminifers from Turkey and their paleoenvironmental significance. Journal of Foraminiferal Research, 36, 152-165.

Hallock, P. \& Talge, H.K. 1994. A predatory foraminifer, Floresina amphiphaga, n.sp., from the Florida Keys. Journal of Foraminiferal Research, 24, 210-213.

Hansen, H. J. 1999. Shell construction in modern calcareous Foraminifera. In: Modern Foraminifera (ed. Sen Gupta, B. K.). Springer, New York, 57-70.

Hansen, H.J. \& Reiss, Z. 1971. Electron microscopy of Rotaliacean wall structures. Bulletin of the Geological Society of Denmark, 20, 329-346.

Hemleben, C., Anderson, O.R., Berthold, W. \& Spindler, M. 1986. Calcification and chamber formation in Foraminifera - a brief overview. In: Biomineralization in Lower Plants and Animals (eds Leadbeater, B.S.C. \& Riding, R.). Oxford, England, Clarendon Press, 237-249.

Hottinger, L. 1978. Comparative anatomy of elementary shell structures in selected larger foraminifera. In: Foraminifera (eds Hedley, R.H. \& Adams, C.G.). New York, Academic Press, 3, 203-266.

Hottinger, L. 2000. Functional morphology of benthic foraminiferal shells, envelopes of cells beyond measure. Micropaleontology, 46, 57-86.

Neumann, C. \& Wisshak, M. 2009. Gastropod parasitism on Late Cretaceous to Early Paleocene holasteroid echinoids - evidence from Oichnus halo isp. n. Palaeogeography, Palaeoclimatology, Palaeoecology, 284, 115-119.

Nielsen, J.K. 2002. Borings formed by Late Cretaceous endobiontic foraminifers within larger benthic foraminifers. Acta Palaeontologica Polonica, 47, 673-678.

Nielsen, K.S.S. 1998. Micro-scale test penetration of the modern foraminifera, a global phenomenon? In: International Symposium of Foraminifera, Forams'98, Proceeding of the Meetings and Abstract with Program (eds Longoria J.F. \& Gamper, M.A.). Sociedad Mexicana de Paleontología, Special Publication, 72-73.

Nielsen, K.S.S. 1999. Foraminiferivory revisited: a preliminary investigation of holes in foraminifera. Bulletin of the Geological Society of Denmark, 45, 139-142.

Nielsen, K.S.S. \& Nielsen, J.K. 2001. Bioerosion in Pliocene to late Holocene tests of benthic and planktonic foraminiferans, with a revision of the ichnogenera Oichnus and Tremichnus. Ichnos, 8, 99-116.

Nielsen, K.S., Nielsen, J.K. \& Bromley, R.G. 2003. Palaeoecological and ichnological significance of microborings in Quaternary foraminifera. Palaeontologia Electronica, 6, 13 p. http:/palaeoelectronica. org/ paleo/2003_1/issue1_03.htm.
Pickerill, R.K., Donovan, S.K. \& Mitchell, S.F. 1998. Ichnology of the late Pleistocene Port Morant Formation of southeastern Jamaica. Caribbean Journal of Science, $34,12-32$.

Pickerill, R.K., Donovan, S.K. \& Portell, R.W. 2002. Bioerosional trace fossils from the Miocene of Carriacou, Lesser Antilles. Caribbean Journal of Science, 38, 106-117.

Samanta, B.K., Bandopadhyay, K.P. \& Lahiri A. 1990. The occurrence of Nummulites Lamark (Foraminiferida) in the Middle Eocene Harudi Formation and Fulra Limestone of Kutch, Gujarat, Western India. Bulletin of the Geological, Mining and Metallurgical Society of India, 55, 1-66.

Schintu, M. \& Degetto, S. 1999. Sedimentary records of heavy metals in the industrial harbour of Portovesme, Sardinia (Italy). The Science of the Total Environment, 241, 129-141.

Sengupta, S. \& Nielsen, J.K. 2009. Bioerosion in Middle Eocene larger foraminifera Nummulites obtusus (Sowerby) from Lakhpat, northwest Kutch, Gujarat, India. Indian Journal of Geosciences, 63, 81-86.

Shroba, C.S. 1993. Taphonomic features of benthic foraminifera in a temperate setting: experimental and field observations on the role of abrasion, solution and microboring in the destruction of foraminiferal tests. Palaios, 8, 250-266.

Sliter, W.V. 1971. Predation on benthic foraminifers. Journal of Foraminiferal Research, 1, 20-29.

Tapanila, L. 2008. The endolithic guild: an ecological framework for residential cavities in hard substrates. In: Current Developments in Bioerosion (eds Wisshak, M. \& Tapanila, L.). Springer-Verlag, Berlin-Heiderlberg, 3-20.

Taylor, P.D. \& Wilson, M.A. 2002. A new terminology for marine organisms inhabiting hard substrates. Palaios, $17,522-525$.

Towe, K. \& Cifelli, R. 1967. Wall ultrastructure in the calcareous foraminifera: crystallographic aspects and a model for calcification. Journal of Paleontology, 41, 742-762.

Wilson, M.A. \& Palmer, T.J. 2001. Domiciles, not predatory borings: a simpler explanation of the holes in Ordovician shells analyzed by Kaplan and Baumiller, 2000. Palaios, $16,524-525$.

Wisshak, M. (ed.) 2006. High-Latitude Bioerosion: The Kosterfjord Experiment. Springer-Verlag Berlin Heidelberg.

Wisshak, M., Gektidis, M., Freiwald, A. \& Lundlv, T. 2005. Bioerosion along a bathymetric gradient in cold-temperate setting (Kosterfjord, SW Sweden): an experimental study. Facies, 51, 93-117. 